Journal of Humanities, Social and Management Sciences (JHSMS)

eISSN: 2788-4791 (online)

https://doi.org/10.47264/idea.jhsms/3.1.3

Vol. 3, No. 1 (January-June 2022), 26-39

https://ideapublishers.org/index.php/jhsms

Research Article

\title{
Blended Learning in ESL: Perceptions about paradigm shift in English Language Institutions of Punjab, Pakistan
}

\author{
Sadaf Siddique* | Riaz Hussain \\ Department of English Linguistics, The Islamia University of Bahawalpur, Pakistan. \\ *Corresponding Author Email: sadaf.siddiq30@gmail.com
}

Received: September 27, $2021 \quad$ Accepted: January 1, 2022

Published: January 22, 2022

\begin{abstract}
Tremendous technological developments have revolutionized educational practices and experiences of English as a Second Language (ESL) teachers and learners at an unprecedented rate. One such educational development is termed as Blended Learning (BL). BL is the method of teaching and learning in which traditional place-based mode of instruction is combined with online teaching and learning. The online mode or environment of BL is not just asynchronous web-enhanced method of delivery of contents rather it also involves synchronous interactions between the teachers and learners via audio and/or video conferencing and cloud-based online meeting apps. Instruction, learning materials and assessment is accessible for learners in traditional face-to-face as well as in online environments. Present study aims to explore ESL learners' perceptions of BL. Questionnaires were used to gather data to examine 282 ESL learners' attitudes toward BL. These ESL learners were enrolled in ESL courses in different public and private institutes of Punjab, Pakistan. The descriptive analysis of the data revealed that most of the students have positive attitude towards BL and they found it helpful in English language learning. Based on the results descriptively drawn from the responses of the subjects of the current study, conclusions are drawn, and recommendations have been offered.
\end{abstract}

Keywords: Blended Learning (BL), English as Second Language (ESL), English Language Teaching (ELT), hybrid learning, learning perceptions.

\section{How to Cite:}

Siddique, S. \& Hussain, R. (2022). Blended Learning in ESL: Perceptions about paradigm shift in English Language Institutions of Punjab, Pakistan. Journal of Humanities, Social and Management Sciences (JHSMS), 3(1), 26-39. https://doi.org/10.47264/idea.jhsms/3.1.3

Publisher's Note: IDEA PUBLISHERS (IDEA Publications Group) stands neutral regarding jurisdictional claims in the published maps and institutional affiliations.

Copyright: (c) 2022 The Author(s), published by IDEA PUBLISHERS (IDEA Publications Group).

Licensing: This is an Open Access article published under the Creative Commons AttributionNonCommercial 4.0 International License (http://creativecommons.org/licenses/by-nc/4.0/) 


\section{Introduction}

Blended Learning (BL) refers to integration of traditional face-to-face (f2f) and online methods of teaching and learning. In BL the learners experience learning in classroom as well as anywhere, anytime through their laptop, mobile phone or any electronic device that supports internet connectivity and cloud-based online meeting applications and software. This mix of $\mathrm{f} 2 \mathrm{f}$ and online environments is not a haphazard mixture of two modes, rather it is a thoughtful integration in which synchronous and asynchronous teaching and learning activities take place in both $\mathrm{f} 2 \mathrm{f}$ and online environments. BL is also sometimes called hybrid learning. It is usually considered beneficial for English as Second Language (ESL) teaching and learning as both of the modes of this method enhance the capacities of learning by offsetting the shortcomings of each mode when used separately. Despite of a few drawbacks such as lack of peer and social interaction, BL's popularity is proliferating because of its efficient feature of flexibility of time and place for both the teachers and learners, individualized or personalized learner centred approach and elimination of geographical barriers (Larysa \& Nataliia, 2021; Myravyova et al., 2021; Owston et al., 2013; Wu et al., 2010). This wide use and integration of technology in academic fields has also impacted the way ESL is taught and learnt. BL is being extensively used for ESL classes. The ESL teachers and learners are benefiting from this combination for enhanced results in English language learning. It strives for best practices by the optimal combination of language course delivery modes to provide the learners with successful learning experiences (Sharma, 2010; Rehman et al., 2021).

BL became a necessity in Pakistan during Covid-19 pandemic. Before this pandemic there were rare instances of using this mix of two modes of instruction and delivery. Though the use of internet for distance learning programs was already being used in some institutions. This elearning was not mixed with f2f instruction usually. However, during three distinct Covid-19 waves the country went under recurrent nationwide or partial lockdowns. During these lockdowns government of Pakistan and federal and provincial educational ministries designed and implemented different schemes which encouraged higher educational institutions to start educational activities initially online-only for a short time span and then in blended method. All public and private universities started blended teaching-learning, private colleges and schools also went online for continuity of educational processes. Similarly, the institutes, colleges and academies which were offering ESL programs and short courses to students also started online classes with combination of f2f classes. BL proved to be an effective way to continue the teaching and learning process during the pandemic. Use of e-Learning which in pre-Covid world was a part of non-formal or distance education became an integral part of conventional education system and teaching and learning of second and foreign languages (see, Aslam et al., 2020; Saeed et al., 2021).

\subsection{Statement of the problem}

The common belief is that technology presents ESL teachers and learners the opportunities to enhance outcomes of the learning endeavours. Many researchers, educationists, and ELTs are particularly suggesting the benefits of BL in ESL contexts. They suggested to expose learners to this technology embedded, latest and flexible method of learning English as their second language. The ESL learners in Pakistan have experienced BL lately due to the emergence of Covid-19 pandemic. Though the addition of technology for instructional purposes was a decision taken to control the spread of deadly virus and still continue the educational processes, 
yet BL has opened up a new horizon for the ESL learners. It provides them with the opportunities to learn without worrying about the geographical limits. They can take part in their ESL classes without having to move to their institutions regularly as courses are divided into on-campus and online classes. So, they can complete their ESL course partially remotely, which saves their travelling time and travel related costs.

However, in Pakistani context, the availability of resources and technological support seems to be a big hurdle in successful implementation of BL to the fullest. These hurdles may cause unsatisfactory opinions of the ESL learners regarding the efficiency and effectiveness of BL. It is a well acknowledged fact that classroom practices and activities are influenced greatly by learners' perceptions about them (Schunk \& Meece, 2012), the success or failure of any educational innovation is heavily influenced by learners' perceptions towards it. Keeping in view this issue, the present research aims to explore learners' perceptions and overall satisfaction with BL in ESL programs.

\subsection{Significance of the study}

The BL is a relatively new concept in Pakistan. Using technology in conjunction with traditional classrooms provides a more comprehensive learning experience. Present research will assist in determining whether BL in Pakistani context is beneficial and accessible or not. This research has both theoretical and practical implications. The findings of the present study will aid in determining the future paths for public and private ESL institutions regarding incorporation of new technologies in second language teaching and learning setups. The research question of the study is do ESL learners perceive Blended Learning (BL) effective for learning English as a second language? Moreover, the research objective to explore ESL learners' perceptions of BL.

\section{Literature review}

English Language Teachers (ELTs) are recognizing BL a suitable method for teaching English as second/foreign language (ESL/EFL), due to the perks it offers to ESL learners and teachers. It is enhancing educational practices and making them easy and innovative with continuously changing technologies and their adoption in instructional designs (Vallam et al., 2021; Wang et al., 2021). Along with numerous other benefits, BL's ability to develop important skills, such as communication, digital literacy and collaboration among the learners have made it increasingly favourite to ESL teachers and researchers.

Bawawa et al. (2021) interviewed English teachers from high schools of an Indonesian district to find out the most widely adopted English language teaching methods during Covid-19. They found that teachers used various methods according to the need and situation. The mostly reported that the reason behind choosing any particular teaching method was learners' interests and preferences. Some methods reported by the teachers are project-based method, grammar translation, Audio-Lingual method, total physical response along with most commonly talked about method namely BL. They revealed that teachers started using digital applications such as Google classroom, Google meet, and other applications offered by Google such as forms and docs etc. ELTs comment on the positive role of these digital apps and social-networking platforms in expediating teaching and learning process as well as communication between the ELTs and the learners. For communication they mostly benefited from WhatsApp. Many other 
similar studies reveal that ESL teachers are favouring BL in their classes. Hence, the application of and research on BL in the field of ESL has increased markedly. Researchers are conducting multidimensional research studies to analyse different aspects, dynamics, benefits and challenges of BL.

Research studies of Adas and Bakir (2013), Akbarov et al. (2018), Graham et al. (2013), Grgurovic (2011), Wang et al. (2021), and Zhang and Zhu (2018) have focused on BL with regard to ESL context especially and assessed its efficacy and limitations experienced and reported by the stakeholders of BL. The use of latest and assorted technologies accompanying traditional classroom strategies of language teaching according to researchers Akbarov et al. (2018), Ja'ashan (2015), Tayebinik and Puteh (2013), and Zhang and Zhu (2018) make BL efficient method of ESL teaching and learning. It provides the learners with an effective learning environment in which they become active participants (Abbacan-Tuguic, 2021) and enhance their language skills effectively.

In BL method the teacher and learners interact more than the traditional or e-learning/distance learning programs. The students get in touch with the teacher and their peers in classroom and then in online mode too. The sense of community is stronger in such classes. Other studies suggest the benefits of BL in terms of its capacity to provide better learning opportunities to ESL leaners. For instance studies conducted by Adas and Bakir (2013) and Grgurovic (2011) indicated that BL is effective to teach English language skills such as reading, writing, listening and speaking. All these four core language skills can be better taught than the traditional or online-only (such as distance learning programs) methods of language teaching.

Adas and Bakir (2013) conducted an experimental study in a Palestinian university to assess the efficacy of BL for teaching English writing skills specifically. After the experiment the learners who were taught ESL writing through BL performed better than those who were taught otherwise. Similarly, Grgurovic (2011) observed the ESL students enrolled in an intensive English learning program in USA. The study mainly focused on improvement in English listening and speaking skills of the learners who were taught in blended environment. The study indicated that $\mathrm{BL}$ is equally helpful in learning all language skills.

The perceptions of the ESL teachers and learners matter a lot in success of any instructional method. The same formula applies to BL. If they perceive BL suitable for their learning endeavours their overall satisfaction and retention enhances (Shohel et al., 2020). If the ESL teachers and learners have positive opinion and their motivation level is high about this technology-enhanced mix of the duo, the success rate is higher. Banditvilai (2016) and Nguyen (2021) found that in BL the learners feel autonomous and free to learn anywhere, anytime. The flexibility of BL is its hallmark. This sense of autonomy enhances their motivational level thus their performance enhances in language classrooms, and they score better in achievement tests. The facility of learner centricity of BL thus proves helpful for learners and ELTs, as the ultimate goal of any ESL class is to enhance learners' performance and achievement.

Grgurovic (2011) also suggests that this blend of f2f and online learning provides learning chances to both the teacher and learners. The ESL teachers learn how to prepare the teaching materials that are suitable for teaching in $\mathrm{f} 2 \mathrm{f}$ classroom and that are also machine friendly (i.e., suitable for teaching in online-mode of blended environment). They also must learn how to integrate all lessons to meet the requirements of the ESL course and how to deliver the contents 
to the learners in efficient and effective way to produce retentive results. The digital skills of teachers also enhance when they engage in preparing their courseware for digital instruction. According to Grgurovic (2011) in BL cases the learners have to become autonomous. They must know how to be active learners. Since in online mode of BL, teacher is not able to physically observe each and every student, it is the intrinsic motivation of the learners that enable them to benefit from the course. When the learners lack this motivation and selfdiscipline they may drift away from the goals of teaching and learning process. So, the flexibility of BL also levies greater responsibility on learners.

Tayebinik and Puteh (2013) investigated the related literature available in the field of ESL in blended environment and suggested that though there are some flaws in this method of teaching, yet it is more efficient than $\mathrm{f} 2 \mathrm{f}$ or e-learning. Another study to find the dynamics of using digital technology in the field of English language teaching and learning, was conducted by Hasnan and Mohin (2021) in Malaysian polytechnic institutions. They focused majorly on the challenges posed by rise of digital technology practices in higher and technical education. Though the inclusion of digital technology makes the process of language learning interactive hence interesting for ESL learners and teachers and it enriches the learning experiences but there are multiple factors that need attention such as the reliability of digital appliances and hardware, the availability of digitally developed learning materials, record-keeping in case of some glitch in hardware or software, time and team management problems, insufficient resources and lack of training initiatives. They rightly pointed out that if the aforementioned problems are elucidated, the acceptance of blended models of English language teaching and learning will amply boost among both, the teachers and the learners. While the technology and facility lapses cause hinderance in adoption readiness (Abbacan-Tuguic, 2021).

Wang et al. (2021) conducted a questionnaire-based survey in Chinese context to see participants' perceptions and its correlation with their motivation and engagement in English language learning course through BL environment. The responses of the learners suggested that BL can be effectively used to get favourable results by providing the learners with autonomy and motivation.

In Pakistan, alike many other countries of the world, BL emerged as a result of Covid-19 pandemic (Shah et al., 2021). But due to the technical and technological lapses most of the students were not satisfied with online-only method of instruction. Shah et al. (2021) suggested that the use of e-learning or online-only mode of instruction is not suitable in Pakistani situation as learners do not have highly sophisticated digital and smart devices and access to fast internet. Computer and internet literacy rate is also not very high thus e-learning should only be opted in emergency cases. But other researchers studying the perceptions of ESL learners about the effectiveness of BL observed a positive outlook of ESL learners towards Aurangzeb (2018) and Kumar and Syed (2021), for instance, studied the perceptions of learners about potential benefits of BL and the findings reveal that learners preferred BL over e-learning or f2 $\mathrm{f}$ separately. Learners commented that they found BL a better option for learning English language than $\mathrm{f} 2 \mathrm{f}$ classes.

\section{Theoretical framework of study}

The Technology Acceptance Model (TAM), developed by Davis (1989) provides theoretical underpinning for the present study. TAM is an information system theory about users' 
acceptance of technology or IT. This model has now become one of the most widely cited in the research of technology diffusion. User acceptance of technology is a vital factor of success or failure of any technology. Similarly, acceptance of the latest technology in educational setup by all stakeholders holds a very importance position. However, as the teachers and learners are the two main participants of teaching and learning environment, their attitude towards accepting or rejecting a new technology holds high grounds and it determines the success or failure of a new educational technology.

Figure 1: The Technology Acceptance Model (TAM) adapted from Davis (1989)

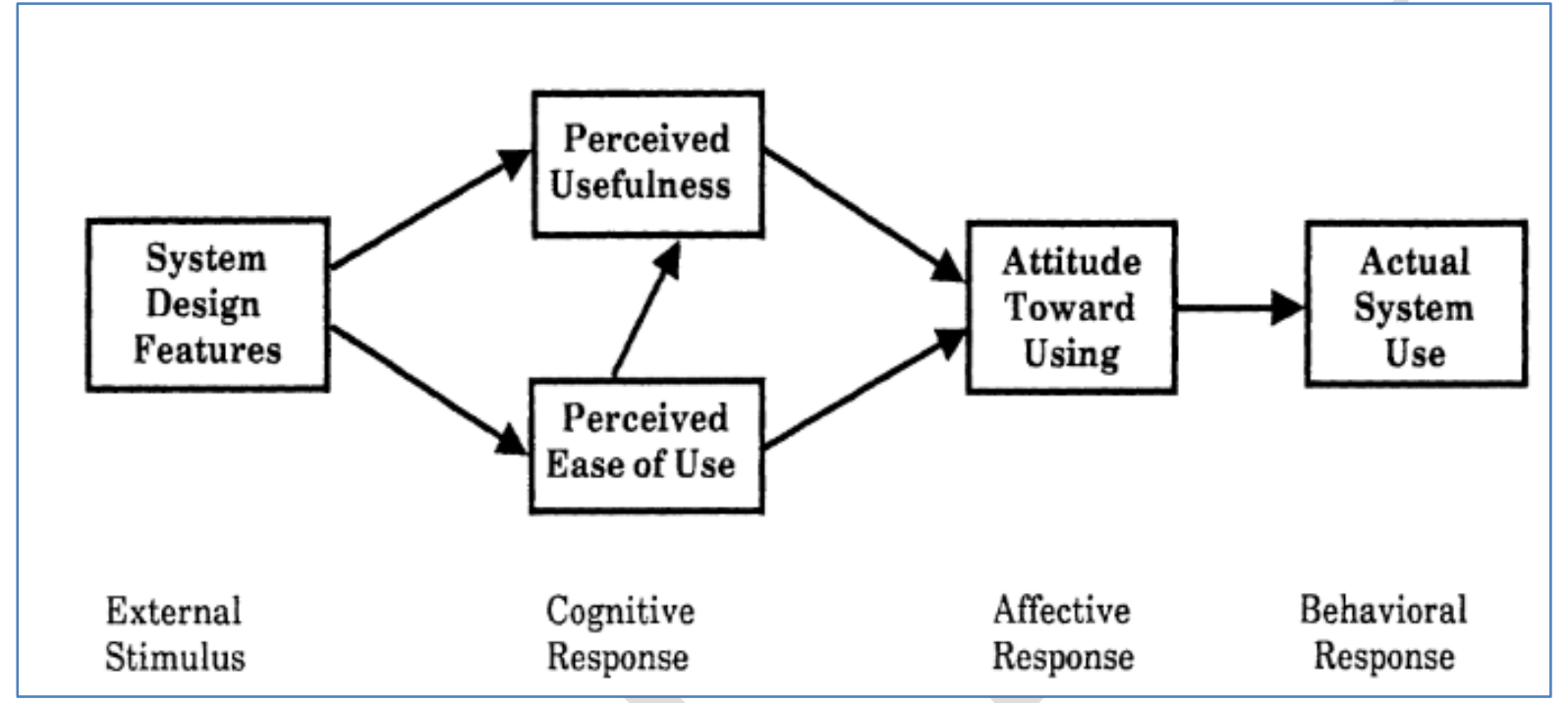

Incorporation of TAM in educational research can be witnessed in the studies of Zhang (2013), Masrom (2007) and Granić and Marangunić (2019). Similarly, in the field of English language teaching and learning Alfadda and Mahdi (2021) found a great correlation between learners' positive attitude towards technology and their success in language learning programs. Rentler and Apple (2020) and Alotumi (2020) also explored positive reception of technology in ESL and EFL contexts. It is evident from research studies, that the constructs of TAM are considered very critical to understand and comprehend students' attitudes towards using technology in educational setups (see Ahmed et al., 2021). For the present study, the researcher found the constructs of TAM very important to examine Pakistani ESL learners' opinions of BL.

\section{Research methodology}

This descriptive study aims to explore the ESL learners' perceptions and overall satisfaction with the BL for which structured questionnaires were used to collect data from respondents.

\subsection{Participants}

The population of the study were the students enrolled in different public and private institute for learning English as their second language through BL environment which incorporated both physical f2 $\mathrm{f}$ and online modes of instruction and delivery of ESL learning materials. The sample of the present study were 282 ESL learners from different cities of Punjab, Pakistan. The researcher took help from her colleagues teaching in different English language teaching institutes across the province. Google survey forms were used to collect data from different 
cities while printed questionnaires were used to gather data from the ESL students of different institutes enrolled in ESL programs in Bahawalpur.

\subsection{Data collection tool}

The data was collected from the respondents using close-ended questionnaire. The researcher designed the questionnaire. For designing the questionnaire, the researcher took help and guidance from Sagarra and Zapata (2008). The piloting of the questionnaire to check its reliability was done prior to actually using the questionnaire for gather data from the sample of the study. The alpha value of the questionnaire was .927, which indicates that the questionnaire was a reliable and internally consistent instrument for data collection for the present study. The adapted questionnaire consisted of 21 questions. These questions were divided into 5 sections namely, learners' preferences, convenience, institutional support and teachers' attitude, suitable for ESL programs and overall satisfaction. The first section contains only 1 question requiring the respondents to choose from different options regarding their preferred mode of ESL instruction i.e., only f2f learning, only online learning, BL or none of these. The remaining 4 sections of the questionnaire have questions related to each label and the learners were required to answer on 5-point Likert scale.

\subsection{Data analysis}

The data collected through Google survey forms and printed questionnaires was entered into SPSS (v-20) and analysed descriptively.

\subsubsection{Reliability of the questionnaire}

The questionnaire consisted of two types of questions, i.e., one question was a multiple-choice type of question while other twenty questions were on 5-point Liker scale. Therefore, the reliability coefficient was calculated for 20 questions of the questionnaire excluding the one multiple-choice type of question. The questionnaire was distributed among 20 ESL students, who were not included in the sample of the study, and the results were analysed using SPSS (v-20). The Cronbach alpha value of 20 questions was .927, which indicates that the questionnaire was reliable.

Table-1: Reliability statistics

\begin{tabular}{|c|c|}
\hline Cronbach's Alpha & No of questions \\
\hline 0.927 & 20 \\
\hline
\end{tabular}

\subsubsection{Gender of the respondents}

The data shows that $53.2 \%$ of the respondents of the questionnaires were females while $46.8 \%$ were male ESL students.

Table-2: Respondents

\begin{tabular}{|l|l|l|l|}
\hline \multicolumn{2}{|l|}{} & Frequency & Percent \\
\hline \multirow{3}{*}{ Valid } & Female & 150 & 53.2 \\
\cline { 2 - 4 } & Male & 132 & 46.8 \\
\cline { 2 - 4 } & Total & 282 & 100.0 \\
\hline
\end{tabular}




\section{Data and results}

\subsection{Learners' preference}

The first section of the questionnaire was about ESL learners' preferences regarding mode of instruction and delivery of contents. This section had only one question i.e., "which English language learning method do you prefer?". The responses of the ESL learners to this question (in table-3) indicate that most of the learners are in favour of BL i.e., 61.7\% of the ESL learners responded that they prefer BL over other modes of instruction and delivery. Whereas $30.5 \%$ respondents preferred only f2f learning mode of ESL and while only a small number of respondents i.e., $7.1 \%$ of ESL learners are in favour of only online method of learning. There are $0.7 \%$ of ESL learners who indicated that they had no interest in any method of learning for their ESL classes.

Table-3: Learners' preferences

\begin{tabular}{|l|c|c|c|c|}
\hline Description & $\begin{array}{c}\text { Only face to } \\
\text { face learning \% }\end{array}$ & $\begin{array}{c}\text { Only online } \\
\text { learning \% }\end{array}$ & $\begin{array}{c}\text { Blended } \\
\text { learning \% }\end{array}$ & $\begin{array}{c}\text { Neither face to } \\
\text { face nor online \% }\end{array}$ \\
\hline $\begin{array}{l}\text { Which English language learning } \\
\text { method do you prefer? }\end{array}$ & $30.5 \%$ & $7.1 \%$ & $61.7 \%$ & $0.7 \%$ \\
\hline
\end{tabular}

\subsection{Convenience}

The second section of the questionnaire consisted of 8 questions. These questions were related to the convenience factor of BL i.e., how convenient was BL for ESL learners? The responses of the ESL learners to these inquires indicate that majority of the learners found BL convenient and easy to use for ESL classes. It offered them flexibility of time and place. It reduced their traveling time and related expenses. Moreover, ESL learners could easily get access to their LMS or online platforms for learning materials and they found online quizzes and assignments easy. But the question 7 i.e. I did not face any technological problem has different responses. We can see in the table- 4 , that $31.2 \%$ respondents have disagreed while $11.0 \%$ have strongly disagreed to the statement. Thus, a total $42.2 \%$ people found themselves facing technological problems while using online mode of BL.

Table-4: Convenience

\begin{tabular}{|l|c|c|c|c|c|}
\hline Description & $\begin{array}{l}\text { Strongly } \\
\text { Disagree }\end{array}$ & Disagree & Neutral & Agree & $\begin{array}{c}\text { Strongly } \\
\text { Agree }\end{array}$ \\
\hline $\begin{array}{l}\text { My blended learning ESL class offered me } \\
\text { flexibility of time. }\end{array}$ & $3.5 \%$ & $3.5 \%$ & $30.5 \%$ & $54.6 \%$ & $7.8 \%$ \\
\hline $\begin{array}{l}\text { My blended learning English class offered me } \\
\text { flexibility of place. }\end{array}$ & $2.1 \%$ & $2.1 \%$ & $22.0 \%$ & $63.1 \%$ & $10.6 \%$ \\
\hline Blended learning reduced my travel time. & $2.1 \%$ & $7.8 \%$ & $23.4 \%$ & $50.4 \%$ & $16.3 \%$ \\
\hline Blended learning reduced my travel expenses. & $0.7 \%$ & $8.5 \%$ & $23.4 \%$ & $53.9 \%$ & $13.5 \%$ \\
\hline $\begin{array}{l}\text { I was able to easily obtain learning resources online } \\
\text { (on LMS, WhatsApp groups, Microsoft Teams etc.) }\end{array}$ & $4.3 \%$ & $14.9 \%$ & $21.3 \%$ & $42.6 \%$ & $17.0 \%$ \\
\hline $\begin{array}{l}\text { I had no problem in using online platforms for } \\
\text { classes (LMS, WhatsApp, Google meet, MS Teams) }\end{array}$ & $8.5 \%$ & $17.0 \%$ & $26.2 \%$ & $33.3 \%$ & $14.9 \%$ \\
\hline I didn't face any technological problems. & $11.0 \%$ & $31.2 \%$ & $19.1 \%$ & $28.4 \%$ & $10.3 \%$ \\
\hline Online quizzes and assignments were easy. & $2.8 \%$ & $7.8 \%$ & $22.0 \%$ & $50.4 \%$ & $17.0 \%$ \\
\hline
\end{tabular}




\subsection{Institutional support and instructors' attitude}

The third section of the questionnaire asked the ESL learners about their experience with BL with regard to institutional support and teachers' attitude. BL cannot become a successful approach of English language teaching if the course/program offering institution lacks basic facilities and doesn't provide necessary support to its students. In addition to institutional support, ESL teachers' attitude is also very important in making a BL program successful. In this section the learners were asked about their experience with their ESL institution and teacher during their BL ESL course. This section consisted of 4 questions. The results to different questions in this section, evident in table-5, suggest that the ESL learners from different cities of Punjab, Pakistan found their institutions very supportive and ESL teachers very cooperative in BL environment.

Table-5: Institutional support and instructors' attitude

\begin{tabular}{|l|c|c|c|c|c|}
\hline Description & $\begin{array}{l}\text { Strongly } \\
\text { Disagree }\end{array}$ & Disagree & Neutral & Agree & $\begin{array}{l}\text { Strongly } \\
\text { Agree }\end{array}$ \\
\hline $\begin{array}{l}\text { Blended learning methods were adequately } \\
\text { explained by my institution. }\end{array}$ & $3.5 \%$ & $7.8 \%$ & $25.5 \%$ & $55.3 \%$ & $7.8 \%$ \\
\hline My institute provided help in any technical problem & $3.5 \%$ & $14.9 \%$ & $22.0 \%$ & $49.6 \%$ & $9.9 \%$ \\
\hline $\begin{array}{l}\text { Contacting my English language teacher was easy } \\
\text { in online mode of blended learning. }\end{array}$ & $0.7 \%$ & $9.2 \%$ & $23.4 \%$ & $48.9 \%$ & $17.7 \%$ \\
\hline $\begin{array}{l}\text { My English language teacher was very cooperative } \\
\text { in blended learning course. }\end{array}$ & $0.7 \%$ & $3.5 \%$ & $18.4 \%$ & $46.8 \%$ & $30.5 \%$ \\
\hline
\end{tabular}

\subsection{Suitable for ESL programs}

This section of the questionnaire aimed to find out learners' opinion regarding BL being suitable for ESL programs. We know that not all teaching methods are equally suitable for each and every course. The learners to responses to 6 questions of this section of questionnaire indicate that ESL learners found BL a good method of teaching and learning of all English language skills i.e., listening, speaking, reading and writing. Table-6 presents a summary of the responses of the ESL learners. We can see that learners found BL an easy and interesting way to learn English language. Moreover, the percentage of the responses that show the positive perceptions of ESL learners towards suitability of BL for all four skills of English language his high. Thus, we can say that BL is suitable for all language skills.

Table-6: Suitability

\begin{tabular}{|l|c|c|c|c|c|}
\hline Description & $\begin{array}{c}\text { Strongly } \\
\text { Disagree }\end{array}$ & Disagree & Neutral & Agree & $\begin{array}{c}\text { Strongly } \\
\text { Agree }\end{array}$ \\
\hline BL makes English language learning easy & $2.8 \%$ & $10.6 \%$ & $22.7 \%$ & $49.6 \%$ & $14.2 \%$ \\
\hline BL makes English language learning interesting & $0.0 \%$ & $8.5 \%$ & $24.1 \%$ & $51.1 \%$ & $16.3 \%$ \\
\hline $\begin{array}{l}\text { BL helped me improve English language } \\
\text { listening skills }\end{array}$ & $0.7 \%$ & $7.1 \%$ & $22.7 \%$ & $51.1 \%$ & $18.4 \%$ \\
\hline $\begin{array}{l}\text { BL helped me improve English language } \\
\text { speaking skills }\end{array}$ & $0.7 \%$ & $11.3 \%$ & $21.3 \%$ & $53.2 \%$ & $13.5 \%$ \\
\hline $\begin{array}{l}\text { BL helped me improve English language } \\
\text { reading skills }\end{array}$ & $1.4 \%$ & $9.2 \%$ & $21.3 \%$ & $50.4 \%$ & $17.7 \%$ \\
\hline $\begin{array}{l}\text { BL helped me improve my English language } \\
\text { writing skills }\end{array}$ & $0.7 \%$ & $8.5 \%$ & $25.5 \%$ & $48.2 \%$ & $17.0 \%$ \\
\hline
\end{tabular}




\subsection{Overall satisfaction}

This is the final section of the questionnaire used for this study. It consisted of two questions regarding overall satisfaction of the ESL learners. The positive responses to the both questions of this section, as can be seen in table-7, are indication of the overall satisfaction of ESL learners with BL. We see that majority of the ESL learners who experienced BL for learning English language have responded that they enjoyed blende learning course and they would like to take part in more BL courses in future. This means that the ESL learners have positive perceptions about BL.

Table-7: Overall satisfaction

\begin{tabular}{|l|c|c|c|c|c|}
\hline Description & $\begin{array}{c}\text { Strongly } \\
\text { Disagree }\end{array}$ & Disagree & Neutral & Agree & $\begin{array}{c}\text { Strongly } \\
\text { Agree }\end{array}$ \\
\hline $\begin{array}{l}\text { I enjoyed blended learning English language } \\
\text { course }\end{array}$ & $2.1 \%$ & $3.5 \%$ & $24.8 \%$ & $54.6 \%$ & $14.9 \%$ \\
\hline $\begin{array}{l}\text { Given opportunity, I would like to take part in } \\
\text { more blended learning courses in future. }\end{array}$ & $2.8 \%$ & $8.5 \%$ & $19.1 \%$ & $49.6 \%$ & $19.9 \%$ \\
\hline
\end{tabular}

\section{Analysis and discussion}

The partial employment of technology in ESL classes seems to be beneficial for language learners. ESL learners' responses from the questionnaire-based survey were analysed using SPSS (v-20) and are presented in results section of this study. In table-3, the findings of the part of questionnaire which was intended to collected data regarding ESL learners' preferences of mode of instruction and delivery of content are presented. It can be observed that the most preferred mode of the majority is BL, as $61.7 \%$ of the respondents esteemed BL as the best mode of instruction for ESL classes. Similarly, when the learners were asked about their experience of BL in terms of convenience (table-4). Only a small fragment of the participants said that they found BL difficult while, most of the learners found it easy and convenient. Institutional support and instructor or teachers' attitude have a great importance in making any teaching-learning program either successful or unsuccessful.

The respondents of the present study i.e., the ESL learners found that their institutions were cooperative. Their institution provided them guidance and help regarding using the BL platforms and provided technical assistance to the ESL learners, the results can be observed in table-5. Likewise, the ESL teachers were readily accessible to the learners through $\mathrm{f} 2 \mathrm{f}$ and online modes and they were cooperative in their $\mathrm{f} 2 \mathrm{f}$ as well as online classes. It is very correctly said that one size doesn't fit all, similarly, no single teaching methodology is suitable for all types of the teaching and learning process. Different academic disciplines have different requirements. The researcher of the present study was cognizant of this fact thus was interested in knowing learners' perceptions about BL's suitability for ESL environment. For the said purpose, the researcher had designed 6 questions in the questionnaire (table-6) to which the learners responded. Their responses reveal that they think BL is suitable way of learning English as a second language. This method of teaching and learning helps them improve their language skills in easy and interesting ways. Finally, the overall satisfaction of the ESL learners with BL was the probed in the questionnaire the table-7 of the results section divulge that BL had a distinguished importance for ESL learners and the participants of the present study were highly satisfied with this approach and method of language teaching. 


\section{Conclusion}

The perceptions of learners, regarding any course, program or method, influence and are influenced by the instructional events and activities (Schunk \& Meece, 2012) and success of a course or program is profoundly affected by their perceptions. The present descriptive study probed into the ESL learners' perceptions of BL. BL, though a well-known method of teaching and learning in developed parts of the world, has emerged in Pakistan as a befitting educational solution in Covid-19 pandemic. With its manifold benefits and flexibilities, BL provided a magnificent blending of Information and Communication Technology (ICT) into all teaching and learning disciplines. It has promising ways of improving English language teaching and learning experiences of both the teachers and the learners.

The researcher of the present study was interested in knowing the point of view of ESL learners about the practices of BL in Pakistani ESL context and the findings of the study reveal that ESL learners have positive outlook on BL. They found it flexible, convenient, and a learner centred approach of language learning. Majority of the participants preferred BL over only f $2 \mathrm{f}$ or only online method of language learning. It is because of the faculty of the BL to accrue the strengths of both the modes, i.e., the f $2 \mathrm{f}$ and the online and vindicating their shortcomings by their strengths.

The BL is deemed to be one of the most convenient methods of language learning as it offers flexibility of time and place along with easy access to learning materials. It is also cost effective as the learners' travel expenses reduce. Now a days, almost every student knows how to operate a computer or smart phone and internet has become a common utility for everyday socialnetworking or entertainment purposes. Usually, the learners find using the online platforms easy for their educational purposes too. However, it is also revealed from the findings of the present study that the learners found their ESL institutions and teachers very supportive in the technical matters. They were properly guided and provided with the technical support in case of any difficulties. As far as, the matter of suitability of the BL for the ESL programs is concerned, majority of the ESL learners reported that their ESL skills enhanced in the BL classes. Hence, all the advantages and conveniences of the BL have added to their overall satisfaction with the program.

The findings of the present study are consistent with other studies such as Aurangzeb (2018) and Kumar and Syed (2021), which suggest that BL is perceived as a remunerative learning method by Pakistani students. They understand the value of technology and its incorporation in their educational system. The researcher of present study deems that this positive attitude and perception of ESL learners towards BL Is due to its superior features such as integration of latest digital technologies into educational paradigm, flexibility of self-paced learning, learners' autonomy and opportunities of interaction and communication with teachers and peers. Thus, the findings of the present study suggest that BL has remarkable scope for ESL teachers and learners. 


\section{References}

Abbacan-Tuguic, L. (2021). Challenges of the new normal: Students' attitude, readiness and adaptability to the blended learning modality. International Journal of English Literature and Social Sciences (IJELSS), 6(2), 443-449. https://dx.doi.org/10.22161/ijels.62.65

Adas, D., \& Bakir, A. (2013). Writing difficulties and new solutions: Blended learning as an approach to improve writing abilities. International Journal of Humanities and Social Science, $\quad 3(9), \quad$ 254-266. http://citeseerx.ist.psu.edu/viewdoc/download?doi=10.1.1.1041.9160\&rep=rep1\&ty $\mathrm{pe}=\mathrm{pdf}$

Ahmed, S. N., Rehman, S. U., \& Khan, S. M. (2021). Online graded assessment of Saudi EFL learners during the Covid-19 pandemic: A successful implication of TAM. Liberal Arts and Social Sciences International Journal (LASSIJ), 5(1), 667-685. https://doi.org/10.47264/idea.lassij/5.1.43

Akbarov, A., Gönen, K., \& Aydogan, H. (2018). Students' attitudes toward blended learning in EFL context. Acta Didactica Napocensia, 11(1), 61-68. https://eric.ed.gov/?id=EJ1177040

Alfadda, H. A., \& Mahdi, H. S. (2021). Measuring students' use of zoom application in language course based on the Technology Acceptance Model (TAM). Journal of Psycholinguistic Research, 50, 883-900. https://link.springer.com/article/10.1007/s 10936-020-09752-1

Alotumi, M. (2020). EFL learning beyond the wall with MALL: College students' perceptions. In Enhancements and limitations to ICT-based informal language learning: Emerging research and opportunities (pp. 138-160). https://doi.org/10.4018/978-1-7998-2116$\underline{8 . \operatorname{ch} 007}$

Aurangzeb, W. (2018). Blended learning classroom environment at university level: A panoramic view of students' perceptions. NUML Journal of Critical Inquiry, 16(1), 96-XI. https://www.numl.edu.pk/journals/subjects/1566298997artcle\%207.pdf

Banditvilai, C. (2016). Enhancing students language skills through blended learning. Electronic Journal of e-Learning, 14(3), 223-232. https://academicpublishing.org/index.php/ejel/article/view/1757/1720

Bawawa, M., Leba, S. M. R., \& Uspayanti, R. (2021). Teaching method used by english teachers during Covid-19 pandemic and new normal era. Ethical Lingua: Journal of Language Teaching and Literature, 8(2), 384-389. https://doi.org/10.30605/25409190.302

Davis, F. D. (1989). User acceptance of Information Systems: The Technology Acceptance Model (TAM). In M. N. Al-Suqri, A. S. Al-Aufi, Information Seeking Behavior and Technology Adoption, S. 205-219. https://quod.lib.umich.edu/b/busadwp/images/b/1/4/b1409190.0001.001.pdf

Graham, C. R., Woodfield, W., \& Harrison, J. B. (2013). A framework for institutional adoption and implementation of blended learning in higher education. The Internet and Higher Education, 18, 4-14. https://doi.org/10.1016/j.iheduc.2012.09.003

Granić, A., \& Marangunić, N. (2019). Technology acceptance model in educational context: A systematic literature review. British Journal of Educational Technology, 50(5), 25722593. https://doi.org/10.1111/bjet.12864

Grgurovic, M. (2011). Blended learning in an ESL class: A case study. Calico Journal, 29(1), 100-117. https://www.jstor.org/stable/calicojournal.29.1.100 
Hasnan, M., \& Mohin, M. (2021). Implementation Of LMS-CIDOS in polytechnic English language classroom: Issues and challenges. Asian Journal of University Education, 17(4), 527-537. https://doi.org/10.24191/ajue.v17i4.16253

Ja'ashan, M. M. N. H. (2015). Perceptions and attitudes towards blended learning for english courses: a case study of students at University of Bisha. English Language Teaching, 8(9), 40-50. http://dx.doi.org/10.5539/elt.v8n9p40

Kumar, A., \& Syed, H. (2021). Facebook as a language learning environment: A descriptive study on ESL learners' perceptions. University of Chitral Journal of Linguistics \& Literature, 2(1), 64-76. https://doi.org/10.33195/jll.v2iI.165

Larysa, D., \& Nataliia, T. (2021). Benefits and challenges of the moodle platform application when teaching foreign languages. Scientific Letters of Academic Society of Michal $\begin{array}{llll}\text { Baludansky (SLASMB), } & \text { 9(1), }\end{array}$ https://ir.vtei.edu.ua/card.php?lang=en\&id=27245

Masrom, M. (2007). Technology acceptance model and e-learning. Technology, 21(24), 81. https://citeseerx.ist.psu.edu/viewdoc/download?doi=10.1.1.554.6982\&rep=rep1\&ty pe $=$ pdf

Myravyova, N., Zhurbenko, N., \& Artyushina, G. (2021). Blended learning for teaching professionally oriented foreign and native languages. Arab World English Journal (AWEJ) Special Issue on CALL(7). https://dx.doi.org/10.24093/awej/call7.9

Nguyen, H. T. T., Sivapalan, S., Hiep, P. H., Van Anh, P. T., \& Lan, N. T. M. (2021). Teaching english as a second language in Vietnam: Transitioning from the traditional learning approach to the blended learning approach. Paper presented at the SHS Web of Conferences. https://doi.org/10.1051/shsconf/202112401003

Owston, R., York, D., \& Murtha, S. (2013). Student perceptions and achievement in a university blended learning strategic initiative. The Internet And Higher Education, 18, 38-46. https://doi.org/10.1016/j.iheduc.2012.12.003

Rehman, N., Zhang, W., \& Iqbal, M. (2021). The use of technology for online classes during the global pandemic: Challenges encountered by the schoolteachers in Pakistan. Liberal Arts and Social Sciences International Journal (LASSIJ), 5(2), 193208. https://doi.org/10.47264/idea.lassij/5.2.13

Rentler, B. R., \& Apple, D. (2020). Understanding the acceptance of e-learning in a Japanese university English program using the technology acceptance model. APU Journal of Language Research, 5, 22-37. https://doi.org/10.34409/apujlr.5.0_22

Saeed, B., Ullah, A., \& Khan, M. A. (2021). Attitude of university students on online teaching under corona virus pandemic situation in Pakistan. Liberal Arts and Social Sciences International Journal (LASSIJ), 5(1), 28-40. https://doi.org/10.47264/idea.lassij/5.1.3

Sagarra, N., \& Zapata, G. C. (2008). Blending classroom instruction with online homework: A study of student perceptions of computer-assisted L2 learning. ReCALL, 20(2), 208224. https://doi.org/10.1017/S0958344008000621

Schunk, D. H., \& Meece, J. L. (2012). Student perceptions in the classroom. Routledge. https://doi.org/10.4324/9780203052532

Shah, E., Quds, T., Siddiqui, F., Mansoor, S. K., \& Ahmed, S. A. (2021). Online learning experience of students during Covid-19 pandemic in Karachi, Pakistan. Paper presented at the International Conference on Medical Education (ICME 2021). https://doi.org/10.2991/assehr.k.210930.028

Sharma, P. (2010). Key concepts in ELT: Blended learning. ELT Journal, 64(4), 456-458. https://doi.org/10.1093/elt/ccq043 
Shohel, M. M. C., Cann, R., \& Atherton, S. (2020). Enhancing student engagement using a blended learning approach: Case studies of first-year undergraduate students. International Journal of Mobile and Blended Learning (IJMBL), 12(4), 51-68. doi:10.4018/IJMBL.2020100104

Tayebinik, M., \& Puteh, M. (2013). Blended Learning or E-learning? arXiv preprint arXiv:1306.4085. https://arxiv.org/ftp/arxiv/papers/1306/1306.4085.pdf

Vallam, R. D., Bhatt, P., Mandal, D., \& Narahari, Y. (2021). Improving teacher-student interactions in online educational forums using a Markov Chain based Stackelberg Game Model. arXiv preprint arXiv:2112.01239. https://arxiv.org/pdf/2112.01239.pdf

Wang, N., Chen, J., Tai, M., \& Zhang, J. (2021). Blended learning for Chinese university EFL learners: learning environment and learner perceptions. Computer Assisted Language Learning, 34(3), 297-323. https://doi.org/10.1080/09588221.2019.1607881

Wu, J.-H., Tennyson, R. D., \& Hsia, T. L. (2010). A study of student satisfaction in a blended e-learning system environment. Computers \& Education, 55(1), 155-164. https://doi.org/10.1016/j.compedu.2009.12.012

Zhang, M. (2013). Supporting middle school students' online reading of scientific resources: moving beyond cursory, fragmented, and opportunistic reading. Journal of Computer Assisted Learning, 29(2), 138-152. $\quad$ https://doi.org/10.1111/j.1365$\underline{2729.2012 .00478 . \mathrm{x}}$

Zhang, W., \& Zhu, C. (2018). Comparing learning outcomes of blended learning and traditional face-to-face learning of university students in ESL courses. International Journal on E-Learning, 17(2), 251-273. https://eric.ed.gov/?id=EJ1175017 